\title{
New Approach of Structural Setting of Gold Deposits in Birimian Volcanic Belt in West African Craton: The Example of the Sabodala Gold Deposit, SE Senegal
}

\author{
Serigne Sylla1, Mamadou Gueye ${ }^{2}$, Papa Malick Ngom $^{3}$ \\ ${ }^{1}$ Teranga Gold Corporation, Dakar, Senegal \\ ${ }^{2}$ Institute of Earth Sciences, Université Cheikh Anta Diop, Dakar, Senegal \\ ${ }^{3}$ Département de Géologie, Faculty of Sciences and Technics, Université Cheikh Anta Diop, Dakar, Senegal \\ Email: serigne.sylla@terangagold.com, *mamadou1.gueye@ucad.edu.sn, papam.ngom@ucad.edu.sn
}

Received 4 February 2016; accepted 28 March 2016; published 31 March 2016

Copyright (C) 2016 by authors and Scientific Research Publishing Inc.

This work is licensed under the Creative Commons Attribution International License (CC BY).

http://creativecommons.org/licenses/by/4.0/

(c) †) Open Access

\section{Abstract}

The Sabodala gold deposit in the Mako volcanic Belt (SE-Senegal, West African Craton) occurs in mafic and ultramafic rocks overlain by clastic sedimentary rocks and felsic volcanic-volcaniclastic sequences. It is a structurally controlled mesothermal vein gold deposit developed in deformed rocks units near the Falombo pluton. The Sabodala Goldfield comprises several faults systems striking N-S to NE-SW. New structural evolution consisting of both thrusting and transcurrent events has been defined for the Sabodala Goldfield. The majority of the gold at Sabodala occurs on the western flank of a large, doubling plunging dome (the Sabodala Antiform) and is also associated with sinistral wrenching that overprints early structures within the Sabodala Mine. The gold bearing veins are hosted by flat lying and NW-trending shear zones. The NW-trending faults acted as transfers syn-gold mineralization, although only discrete segments of these faults were active during the main stage of gold mineralization. Late exhumation resulted in extension along fault zones was responsible for the juxtaposition of medium and low grade metamorphic rocks. The granitic suite of the Falombo pluton is linked to exhumation. Final dextral transpression postdating exhumation produced shearing and folding. Gold lodes developed during brittle deformation are associated with high fluid pressures in a northwest-southeast shortening regime. These are termed mainly the Sabodala deposit, and secondary the Niakafiri and Masato deposits.

\footnotetext{
"Corresponding author.
}

How to cite this paper: Sylla, S., Gueye, M. and Ngom, P.M. (2016) New Approach of Structural Setting of Gold Deposits in Birimian Volcanic Belt in West African Craton: The Example of the Sabodala Gold Deposit, SE Senegal. International Journal of Geosciences, 7, 440-458. http://dx.doi.org/10.4236/ijg.2016.73034 


\section{Keywords}

\section{Gold, Mesothermal, Thrusting, Transcurrent, Sabodala, Birrimian, Senegal, West Africa}

\section{Introduction}

Gold mineralization in many deposits of the WAC (West African Craton) is empirically associated with shear zones domes and regional antiforms (e.g. Damang, Loulo, Yatéla, Sadiola...). These deposits are structurally controlled, and are deposited from mesothermal syn- to post-metamorphic fluids in $\mathrm{D}_{2}$ deformation zones (Eisenlohr and Hirdes [1]; Blenkinsop et al., [2]; Mumin and Fleet [3]; Oberthür et al., [4] [5]; Yao et al., [6]; Allibone et al., [7]; Feybesse et al., [8]; Harcouët et al., [9], Gueye et al., [10]).

The Paleoproterozoic Mako belt, situated in the Kedougou Kenieba Inlier, southeastern Senegal (Figure 1), hosts a number of small gold deposits along with Sabodala, the largest, currently operational gold mine. The structural setting, mineralization and fluid compositions of these Au-occurrences exhibit many similarities to
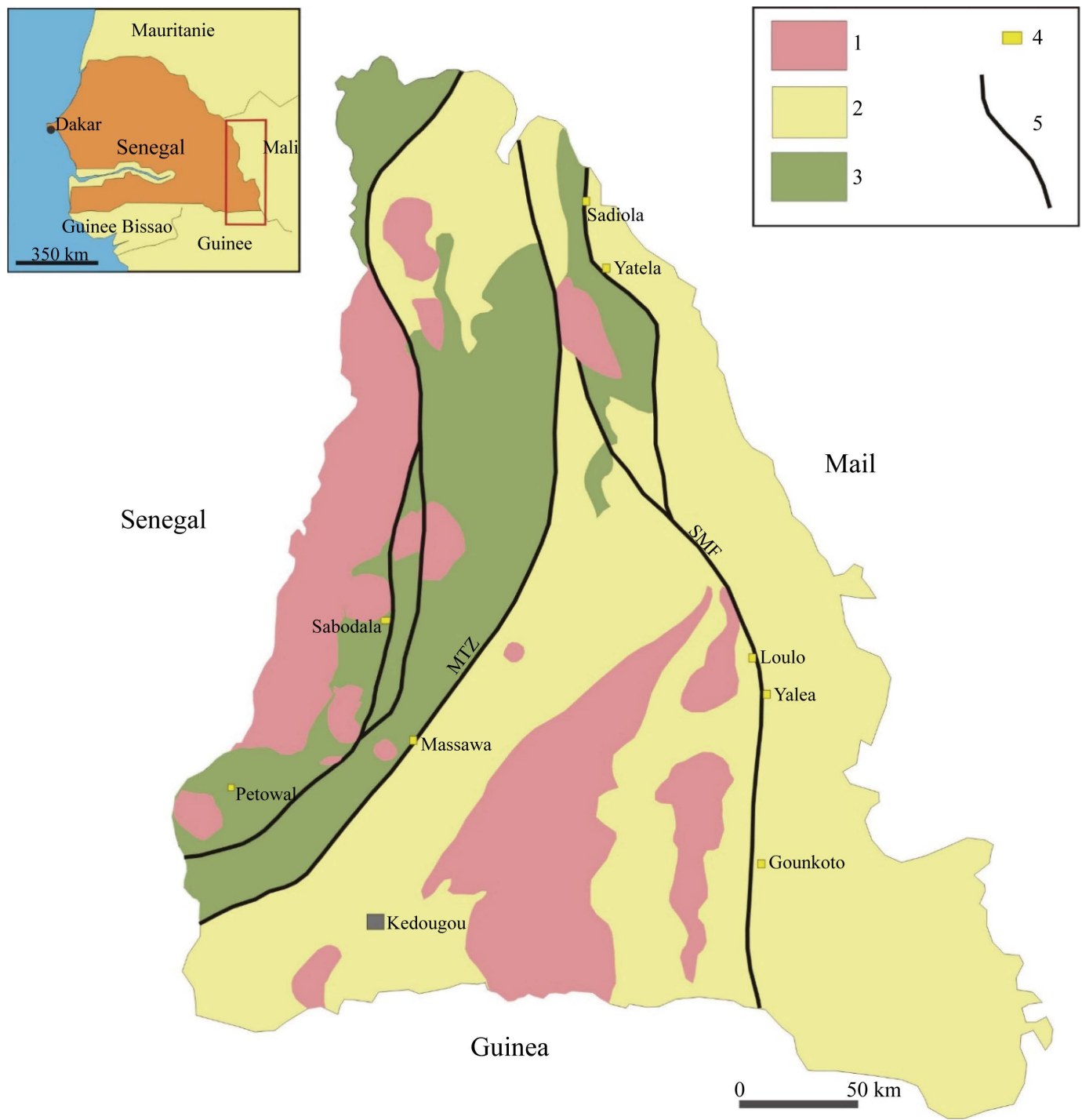

Figure 1. Simplified geological map of the Kedougou-Kenieba Inlier. Explanation: 1: Granites; 2: Volcano sedimentary; 3: Volcanics; 4: Major gold projects; 5: Main gold bearing gold bearing shear systems. 
typical greenstone-hosted mesothermal lode gold deposits, or orogenic gold deposits (Gueye et al., [10]). Although, the mineralization at Sabodala has drawn the attention of some workers (Sylla and Ngom [11], Gueye et al., [10]) but very little effort has been made to evaluate the geology and gold mineralization in the Mako Belt. According to Gueye et al., [10]), the major gold deposits in the Mako Belt, including those at Sabodala area, are structurally controlled, and several lie in the immediate vicinity of shear zones and fold hinges. Understanding the relationship between shear zone system and gold mineralization has been the subject of major scientific and exploration efforts (Gueye et al., [10]), yielding many important exploration models.

The Sabodala area, located in the Mako Belt in Southeastern Senegal (Figure 1), contains a number of large gold deposits as Sabodala (3 Moz), Masato (1, $3 \mathrm{Moz}$ ), Goulouma (0, $9 \mathrm{Moz}$ ) and related satellite ore bodies that are concentrated near shear zones and in the hinge of the regional antiform. Near the deposits are a number of granite domes, buried at depth beneath the greenstone stratigraphy carapace. One dome (Falombo) in particular, is centred beneath the major gold deposit of the goldfield - the Sabodala deposit.

This article presents a revised structural interpretation for a component of the world class Sabodala Goldfield in the Birimian Craton of Western Africa and a revised structural map for a major segment of the Sabodala Goldfield to provide a framework for the revised geological model.

\section{Geological Setting}

The Paleoproterozoic Birimian terranes form a major part of the West African Craton (Bessoles [12]). They form narrow sedimentary basins and linear or arcuate volcanic belts corresponding to a period of accretion around 2.1 Ga (Abouchami et al., [13]; Boher et al., [14]; Taylor et al., [15]; Dia et al., [16]; Pawlig et al., [17]) and are affected by the Eburnean orogeny (2.1 and 2.0 Ga) (Bonhomme, [18]; Liegeois et al., [19]; Gueye et al., [20]). The Eburnean tectonothermal event has been interpreted as occurring as a period of Birimian volcanic eruption, intrusion of granitoids and a period of metamorphism, uplift and erosion (2130 Ma - 1980 Ma, Feybesse et al., [8]). Emplacement of sub-volcanic plutons such as occurred during the Eburnean tectono-thermal event around 2070 Ma (Gueye et al., [20] [21]; Hirdes and Davies, [22]; Diene et al., [23]) ago may have contributed to the formation of late, discordant epigenetic veins, vein systems and stockwerks in the Birimian. The lode gold deposits in the Birimian are concentrated along the contacts of the volcanic belts with the sedimentary basins. These contacts are often associated with supraregional shear zones.

The structural evolution of the Early Proterozoic is interpreted by different authors as monocyclic (Leube et al., [24]; Abouchami et al., [13]) or polycyclic (Feybesse et al., [8] [25]; Ledru et al., [26]; Milési et al., [27]) with the development of:

(a) a regional foliation at $2.1 \mathrm{Ga}$, associated with a greenschist-facies metamorphism and attributed to the collision event $\left(\mathrm{D}_{1}\right)$ followed by;

(b) superimposed structures related to regional sinistral and dextral shear zones (transcurrent phases $\left(D_{2}\right.$ and $\left.\mathrm{D}_{3}\right)$ ) postdating the intrusions of the basic to granodioritic plutons. Most Birimian gold mineralization appears to be associated with the $\mathrm{D}_{2}$ deformation which is related to the transition from a compressional tectonic setting (thrusting) to a transcurrent (strike slip) setting (Feybesse et al., [8]).

The Kedougou Kenieba Inlier (KKI) (Paleoproterozoic of Eastern Senegal) is a portion of the West African Craton (WAC) containing a granite-greenstone terrain that experienced distinct periods of magmatic, tectonic activities and gold mineralization. In the inlier, gold occurrences and large-scale transcurrent shear zones like the Senegal-Mali shear zone and the Main Transcurrent Shear Zone (MTZ) are spatially associated, suggesting a genetic link between tectonics and mineralization. The Senegal-Mali shear zone is one of the most productive regions in West Africa and includes the Loulo and Sadiola districts in western and northern Mali respectively. The MTZ include the Massawa deposit. Economically significant gold associated fault zones in the KKI include the MTZ fault zone and SMF zone. On the local scale however, most gold deposits are hosted in second-and third order structures, which are considered to be more favorable dilational sites for gold deposition. Paleoproterozoic lode gold deposits are spatially associated with brittle-ductile shear zone that range from well-defined individual shear zone to large scale shear zone systems. Quartz-sulphide gold vein systems exploit pre-existing through going regional structures.

The gold deposits in the Mako Belt are mostly hosted in metavolcano sedimentary rocks belonging to the Mako supergroup and subordinately in sheared diorite, both having ages between 2,150 and 2,170 Ma. These sequences are interpreted (Dia et al., [16]; Pawlig et al., [17]) as accretionary assemblages and related to a Pa- 
leoproterozoic orogen. Furthermore, most of the deposits are located close to the interpreted boundary zone between the Mako and the Diale-Dalema supergroup (Figure 1). Wall rock alteration is dominated by retrograde sericite-pyrite and local chlorite-carbonate assemblages.

NE-SW-trending volcanic belts and sedimentary basins of the Paleoproterozoic Birimian Supergroup (2.2 $2.0 \mathrm{Ga}$ ) dominate the geology of Senegal (Abouchami et al., [13]; Hirdes et al., [28]; Taylor et al., [15]; Davies et al., [29]). Two major Birimian supergroups are generally distinguished (Figure 1):

- the Mako supergroup is made up of bimodal volcanics dominated by tholeiitic basalts. This volcanic belt, which hosts the Sabodala gold mine, is a volcanic-dominated paleoproterozoic greenstone belt in the West African Craton. It consists largely of basaltic, frequently carbonate altered flow rocks and minor intercalated volcaniclastics, ultramafic (pyroxenitic), subvolcanic intrusions and numerous relatively small, massive biotite and amphibole-bearing TTG granitoids which resemble the synvolcanic, comagmatic belt-type granitoids of Ghana and eastern Côte d'Ivoire (Doumbia et al., [30]; Oberthür et al., [5]). The structural feature commonly observed in the supracrustal rocks is characterized by a succession of large synclines and antiforms delimited by regional-scale, brittle-ductile shear zones, with a general N-S orientation, for the most part of the greenstone belt, and E-W to NW-SE in the southern area (Ledru et al., [26]; Milési et al., [27]). These structures have been related to a $\mathrm{D}_{2}$ deformation event, by far the most prominent in the region, during which the bulk of the felsic intrusives were emplaced (Gueye et al., [20]). Post- $\mathrm{D}_{2}$ intrusions are subordinate and refer to some rounded to slightly ellipsoidal isotropic bodies of granodiorite composition, which occur enclosed in the mafic volcanic rocks. The boundary of the Mako belt with the adjacent Diale-Dalema sedimentary basin is partly transitional and characterized by interlayering of metavolcanics and basin metasediments (Bassot, [31]; Ngom et al., [32]).

- the Dialé-Daléma basin is composed predominantly of detrital and volcaniclastic rocks of felsic intermediate affinity associated locally with limestones (Bassot, [33]).

Both Birimian supergroups are intruded by syn-, late- and post-tectonic granitoids (Hirdes et al., [22]; Cheilletz et al., [34]; Pons et al., [35]; Dioh et al., [36]; Gueye et al., [20]), which are particularly abundant in the Mako supergroup. The Diale-Dalema metasediments are interpreted by the present authors as parts of the same sedimentary basin which is centrally intruded by the Saraya batholith extensive basin-type granitoid.

\section{Sabodala Gold Deposit}

The Sabodala gold deposit is one of the largest eburnean orogenic lode gold in the KKI with more than 3 million onces. The deposit is hosted by Birimian rocks of the Mako Belt. This region is composed mainly of metavolcanic and metasedimentary sequences and intruded by large granitoids batholith associated with Eburnean orogenic cycle, which was active between 2200 and 1800 Ma (Dia et al., [16]; Hirdes and Davies, [22]; Gueye et al., [20]). The Sabodala shear zone, located at the east of the deposit, forms the major structural feature in the region. The shear zone extends largely the contact between Falombo and Bouroumbourou granitoids and contains deformed volcanic and volcano sedimentary formations, which have been intruded by the granitoid plutons. This regional shear zone is marked by deformed volcanic and volcano sedimentary which are intruded by Falombo and Bouroumbourou granitoids.

The Sabodala orebody is within a broad NW-trending shear zone, which is locally referred to as the NW Shear Zone and interpreted as a second order shear of the main Sabodala shear. The host rock is a heterogeneous sequence of metaperidotites, metavolcanics, metavolcanosediments and metasediments that extends from the basaltic footwall through the mineralized section to the basaltic hanging wall.

The Sabodala gold deposit in the Mako Belt is hosted by highly strained albite-bearing tuff developed within the Sabodala shear zone. Below the supergene cover, the stratigraphy of the deposit is comprised of intermediate to felsic tuffs and jasper in addition to subordinate meta-andesite, metasedimentary and volcaniclastic rocks associated to mafic volcanics. This volcano-sedimentary sequence underwent deformation under ductile, ductile-brittle conditions. The hydrothermal alteration is characterized by silicification, carbonatization, albitization and sulfidation. The mineralization style consists of quartz-carbonate veins, in addition to sulfides that occur both in the veins and as disseminations in the wall rock. Sylla and Ngom, [11] show that the hydrothermal mineralization, constitued of auriferous pyrite, is disseminated in the siliceous-carbonate stockwerk and in the host rock. The Sabodala area has undergone multiple episodes of eburnean deformation and is bounded by the NNE trending regional Ayoub Fault to the West, and by the "Mylonite" Fault to the East (Figure 2). 


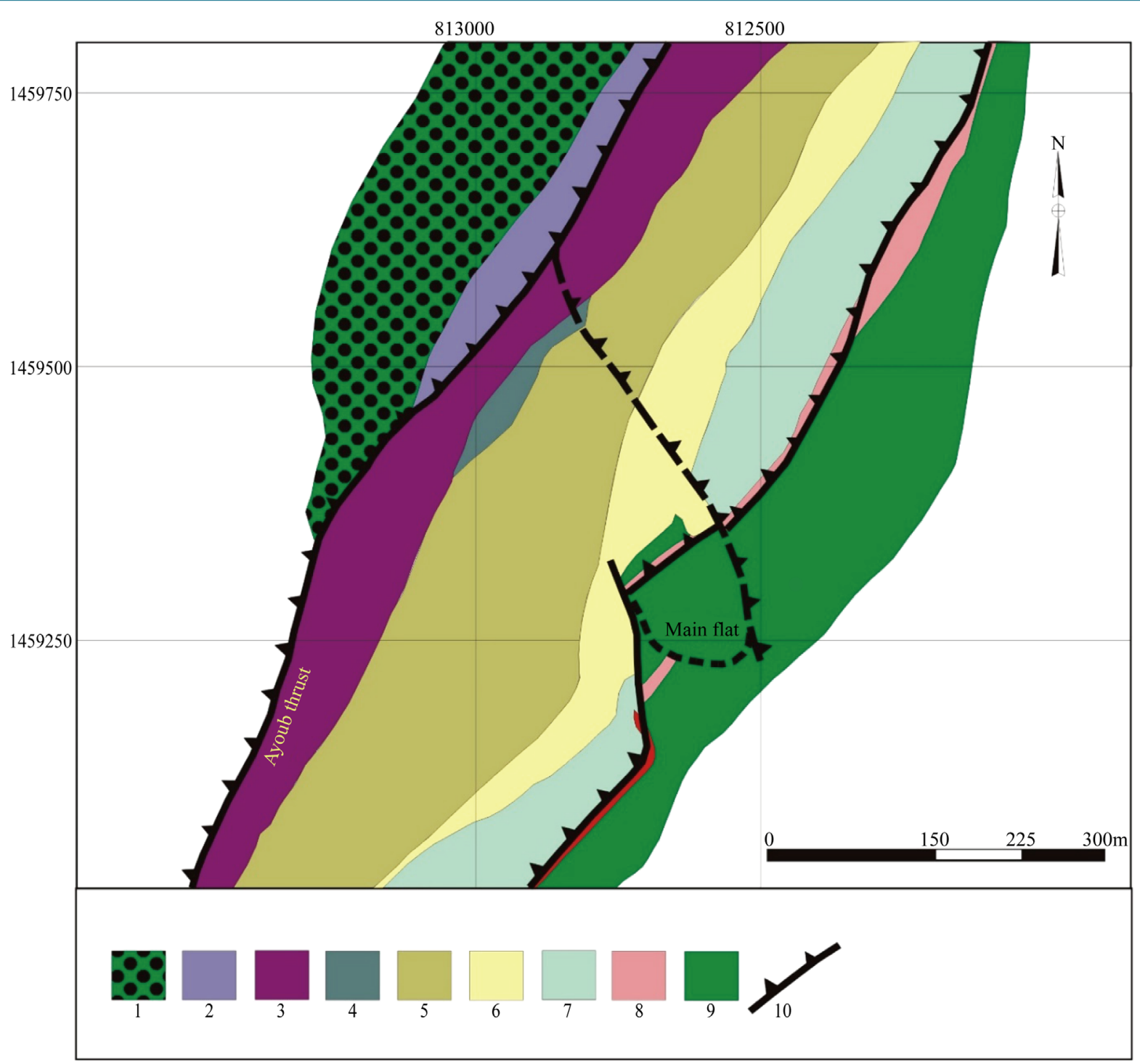

Figure 2. Schematic lithostructural map of the Sabodala area indicating the location of the Sabodala mine. The margin of the mine are defined by the Masato Shear Zone and the Ayoub Fault. 1: footwall pillow basalt; 2: ultramafic rocks; 3: high strain zone; 4, 5: quartzdiorite; 6: mafic central; 7: volcano sedimentary components; 8: felsic dykes; 9: pillow basalt; 10: faults.

\section{Lithology}

To the west, the base of the local stratigraphy of the Mako volcanic belt is composed of mafic and ultramafic rocks overlain by clastic sedimentary rocks and felsic volcanic-volcaniclastic sequences (Figure 3). This "Sabodala volcanogenic rocks" has broadly oriented N-S to NNE-SSW with vertical dip trending towards W to NW.

Towards the NW of the studied area, this volcanic complex is intruded by the Falombo granitic pluton.

Mapped metamorphosed ultramafic units are included in the mafic volcanic units (Figure 3). They are largely outcropped at the eastern part of the Sabodala deposit along the regional shear zones where the rocks are patched of green fuchsite and sulfurs. Fresher varieties which retain primary textures are mottled with relict igneous texture suggesting that they mainly comprise intrusive sills and dykes. The rock is largely transformed into talc, serpentine, chlorite, calcite and oxide.

Ngom [37], described for the first time two types of mafic metabasalts with associated subvolcanic mafic intrusions in the Sabodala area. The massive flows are plumose textured metabasalts composed of abundant magnesio- and actinolite hornblendes with minor albitized plagioclase in the devitrified matrice composed of chlorite, epidote, quartz, leucoxenes and oydes (hydroxides and sulfurs). These basalts outcrop at the western 


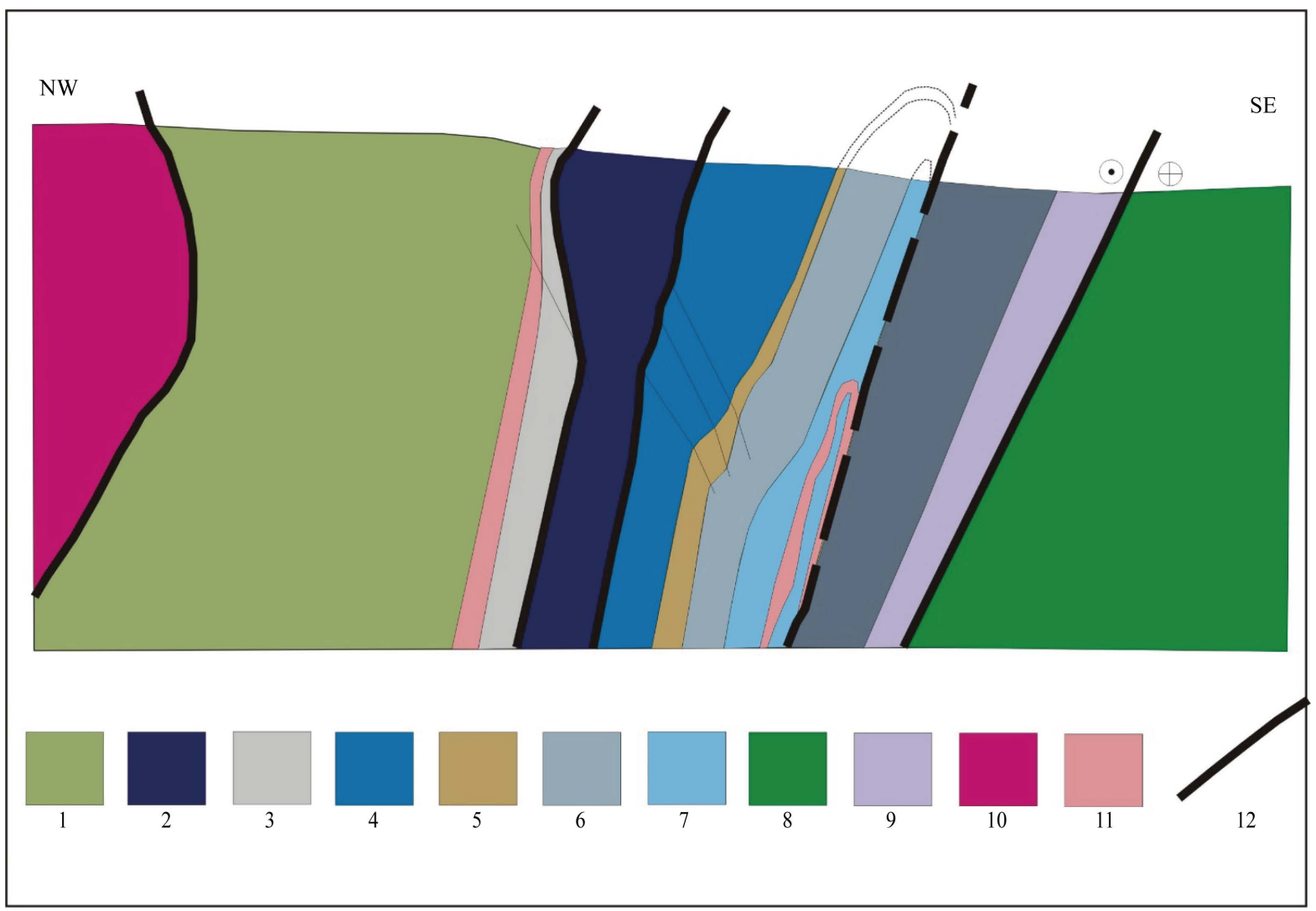

Figure 3. Log section through the Sabodala system: thrust stacking and isoclinal folding has produced repetitions in the mafic-ultramafic statigraphy and the associated layer parallel fabric. Explanation: 1: Falombo granite; 2: lower basalt; 3: felsic dyke; 4: volcanoclastics; 5: ultramafic rocks; 6: diorite quartzite; 7: andesite; 8: volcanoclastics; 9: microdiorite; 10: ignimbrite; 11: shale; 12: upper basalts; 13: faults

parts, are intensively mylonitized by transcurrent faults where the rock is entirely transformed into silica, carbonate, chlorite and epidote associations.

Thick pillowed flows (>300 m) are widespread in all around Sabodala. The vesicles are scarce, but variolites filled of calcite-epidote-albite-quartz associations are locally abundant in the upper parts of the flows. The pillows, less than $20 \mathrm{~cm}$ in size, are sub spherical, and those up to $50 \mathrm{~cm}$ diameter have elongated shape oriented NS with $70^{\circ} \mathrm{W}$ dip. The interstices between pillows may be filled with silicified material without continental sediments. The chilled rim, $1-2 \mathrm{~cm}$ thick, is composed of chlorite, epidote and silicified material. The pillow core is an aphyric metabasalt composed of actinolitic amphiboles with microlitic albitized plagioclases and $\mathrm{Fe}-\mathrm{Ti}$ oxides. The devitrified matrice is replaced by chlorite and epidote and quartz. The mafic metavolcanics form the hanging wall and the footwall of the deposit.

The subvolcanic mafic intrusions are elongated plutons of metagabbros and metadiorites concordant to the faults. They are often dark and layered with centimeter large layer rich pyroxene alternating with layer rich plagioclase. Felsitic metavolcanics are represented by fine grained ignimbrite enclosed within the mafic metavolcanics flows and minor andesitic to rhyolitic dykes with calc-alkaline affinity. Albite plagioclase and quartz porphyries injections are associated to this volcanism and frequently localized with the shear zones.

\section{Volcaniclastic unit:}

This unit, which lies immediately to the west of the jasper horizon, is composed mainly of fine-grained mafic volcanic rocks. The matrix is locally carbonaceous to graphitic composition with dark grey coloration; it forms a subsidiary proportion of the overall unit.

The mafic volcanic material, with its locally rounded or elliptical fragment shapes and rounded chilled fragments may be clastically derived, or hyaloclastic origin frequent in the oceanic mafic flows. Reddish colored jasper fragments and possible thin layers occur throughout the unit where the matrix is abundant. These and the 
locally carbonaceous matrix suggest a significant sedimentary component to the unit.

Like the adjacent mylonitic chert unit, this unit has localized high strain manifested as elevated foliation intensity and flattening of clasts, forming with the mylonite chert and locally more highly strained lithologies to the west, a part of the "Sabodala Shear Zone".

Dykes and sills: Feldspar-quartz+/- amphibole porphyritic felsic dykes and sills with NNE trends and steep dips that typically vary between 0.5 and several meters in thickness intrude the mafic-ultramafic sequence. These occur most commonly in altered shear or fault zones often spatially associated with gold mineralization.

Two varieties are distinguished:

- phenocryst-rich varieties often have a late or post-mineralization and post-alteration timing, including a prominent dyke which intrudes along the chert unit at Sabodala, and which cuts across and truncates mineralized quartz veins and breccias;

- quartz-feldspar porphyritic dykes with lower phenocryst abundance were noted to have deformed margins, and may be affected by quartz veining and alteration, suggesting a pre- or early, mineralization timing.

A set of these earlier dykes occurs in the Masato Shear Zone, spatially associated with gold mineralization and deformation. The dykes of both ages are similar in texture; if they are comagmatic they would imply that igneous activity overlapped with gold mineralization.

Mylonitic Chert unit: Lenses of jasper extended from the Sabodala gold deposit to the North of Falombo are associated with the volcanic and volcano sedimentary rocks. They are often mylonitized. The mylonitic chert unit comprises a steeply dipping, north-northeast trending, banded siliceous unit which contains alternating layers of fine grained grey quartz, white quartz (locally as sheeted veinlets) and grey carbonaceous phyllite. In outcrop exposures it locally exceeds $10 \mathrm{~m}$ in thickness. It forms a marker horizon which is traceable for more than 4 $\mathrm{km}$ between Falombo to the Sabodala deposit. Tectonically early, bedding parallel quartz veins are frequently developed, and may comprise $>20 \%$ of the unit in some locations.

\section{Intrusive Rocks}

Two types of granitoid plutons have been identified in the region; a homogeneous potassic, pink leucogranite referred to as the Falombo granite to the west of the deposit, and an older phase comprising a group of biotite granites known as the Bouroumbourou suite to the north-east of the deposit (Figure 4). These intrusive plutons are associated with mafic and felsic sills and dykes. They provide a host for many of the early discoveries in the Sabodala area.

The Falombo pluton is mostly medium to coarse-grained and equigranular to weakly porphyric texture (Figure 5(a)). It is characterized by distinctive pink K-feldspar megacrysts, set in a gray, equigranular, hypidiomorphic groundmass of subeuhedral plagioclase, anhedral microperthite, quartz, and biotite with subordinate dark green hornblende, and titanite (Figure 5(b)). The Falombo pluton contains well-developed, interconnected miarolitic textures (Figure 5(c) \& Figure 5(d)). In thin section, microfractures and dissolution cavities commonly cut primary igneous K-feldspar, plagioclase, and quartz grains, but also follow planes of weakness that include the boundaries between individual grain, and exsolution lamellae in perthite grains (Figure 5(e) \& Figure 5(f)). Medium- and fine-grained domains with sharply transitional contacts can be distinguished (Figure 5). Alteration assemblage includes muscovite, chlorite, and calcite and are also localized in miarolitic cavities (Figure 5(c) \& Figure 5(d)). These are similar in appearance to network miarolitic cavities in granite described by Candela and Blevin [38], which are interpreted to reflect crystallization from volatile-rich magma.

The Falombo granite has been subjected to both internal volumetric and external tectonic stresses and as a result is overprinting by joints, fractures, faults and shears. The internal volumetric stress involved intrusion cooling during eburnean deformation and resulted in the formation of steeply dipping cooling joints. The external tectonic stress was associated with late eburnean deformation, significantly later than intrusion and cooling (Gueye et al., [20]). Sinistral strike slip movement along the Sabodala Fault at this time led to the formation of numerous NS striking faults, shears and fractures that cut and offset the pluton (Figure 4).

\section{Structural Framework}

Lithologies on the Sabodala property are affected by several foliation-forming events, the development of associated shear zones associated with gold mineralization, and late brittle faulting. Several sinistral N-S to NNE-SSW shear zones of regional extension commonly designated “Bransan-Sabodala-Makana corridor” have 


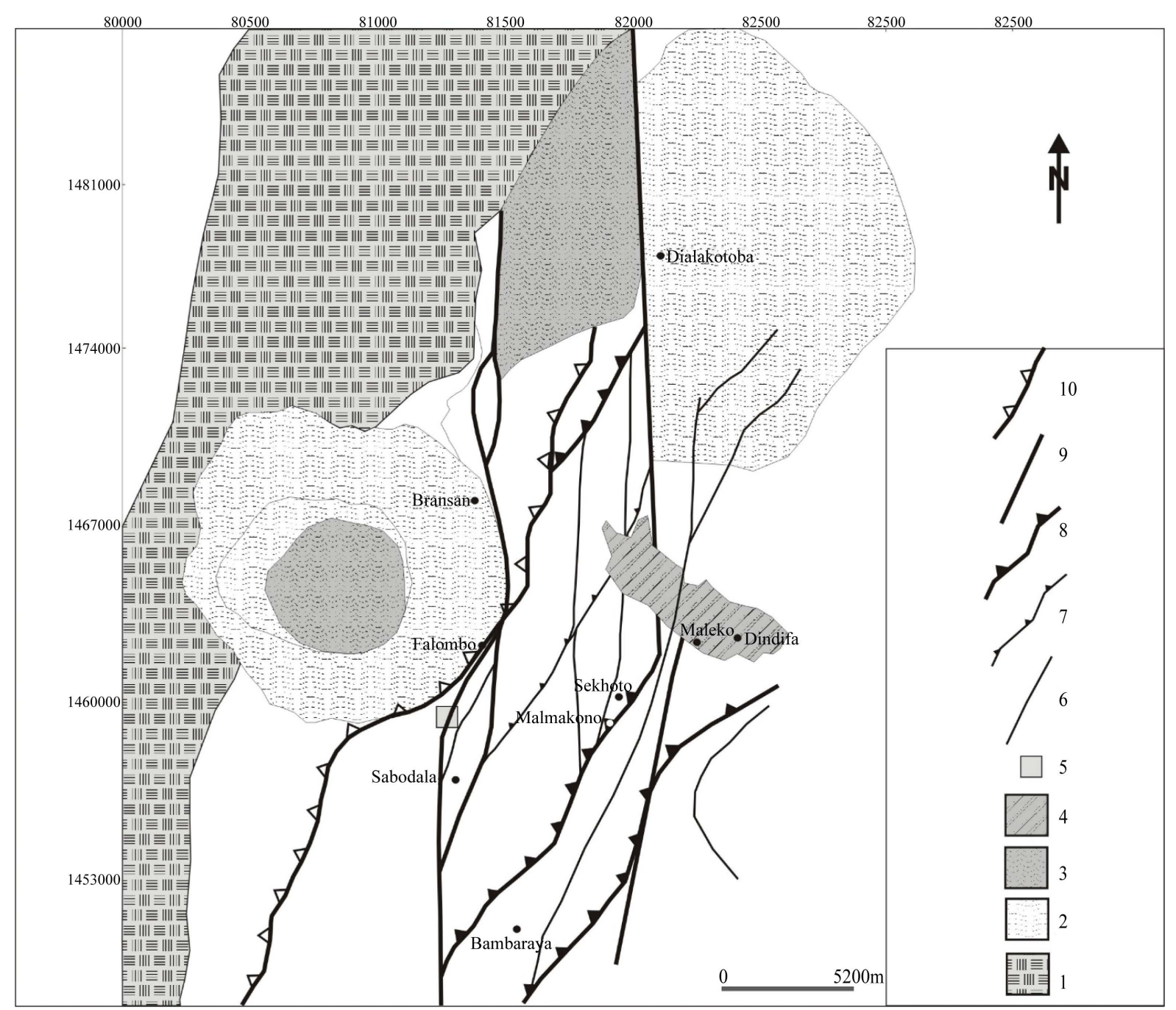

Figure 4. Simplified geological map of parts of the study area. Explanation: 1: Kakadian batholith; 2, 3: Falombo and Bouroumbourou intrusive suites; 4: Dindifa granite; 5: Sabodala deposit; 6, 7: third order structures; 8, 9: second order structures; 10: first order structures.

modeled the lithology. It is resulting a mylonitzed zone of 2 - $3 \mathrm{~km}$ wide and enclosing porphyries and hydrothermal veins. Two of these, Sabodala and Masato shear zone hosted the Sabodala and Masato gold deposits.

The north-northeast-trending Sabodala shear zone is a major shear zone, located within the greenstone sequence of the KKI in the central part of the Mako Belt. Like the Sabodala area, the main geologic feature of this eastern area is a regional-scale anticlinal dome, known as the Sambaya antiform, cut by the regional Niakafiri shear zones.

\subsection{Fault Zones}

The five principal fault zones within the study area are the Ayoub fault, the Sabodala fault, the Masato-fault, the Niakafiri Fault and the "Mylonite", which are interpreted on subprovince-scale maps as continuous for tens of kilometers. They are narrow, linear belts of ductile and brittle-ductile shearing, isoclinal folding, strongly developed foliation, and intense low-grade metamorphic replacement of primary minerals, that was associated with voluminous fluid fluxing. Discontinuous, brittle to brittle-ductile faults with minor displacements occur within the regionally mapped fault zones (Gueye et al., [10]).

Principal structures on the Sabodala property form a steeply west-northwest dipping, northnortheast trending shear zone network which has previously been referred to as the "Sabodala Shear Corridor". The largest, and 


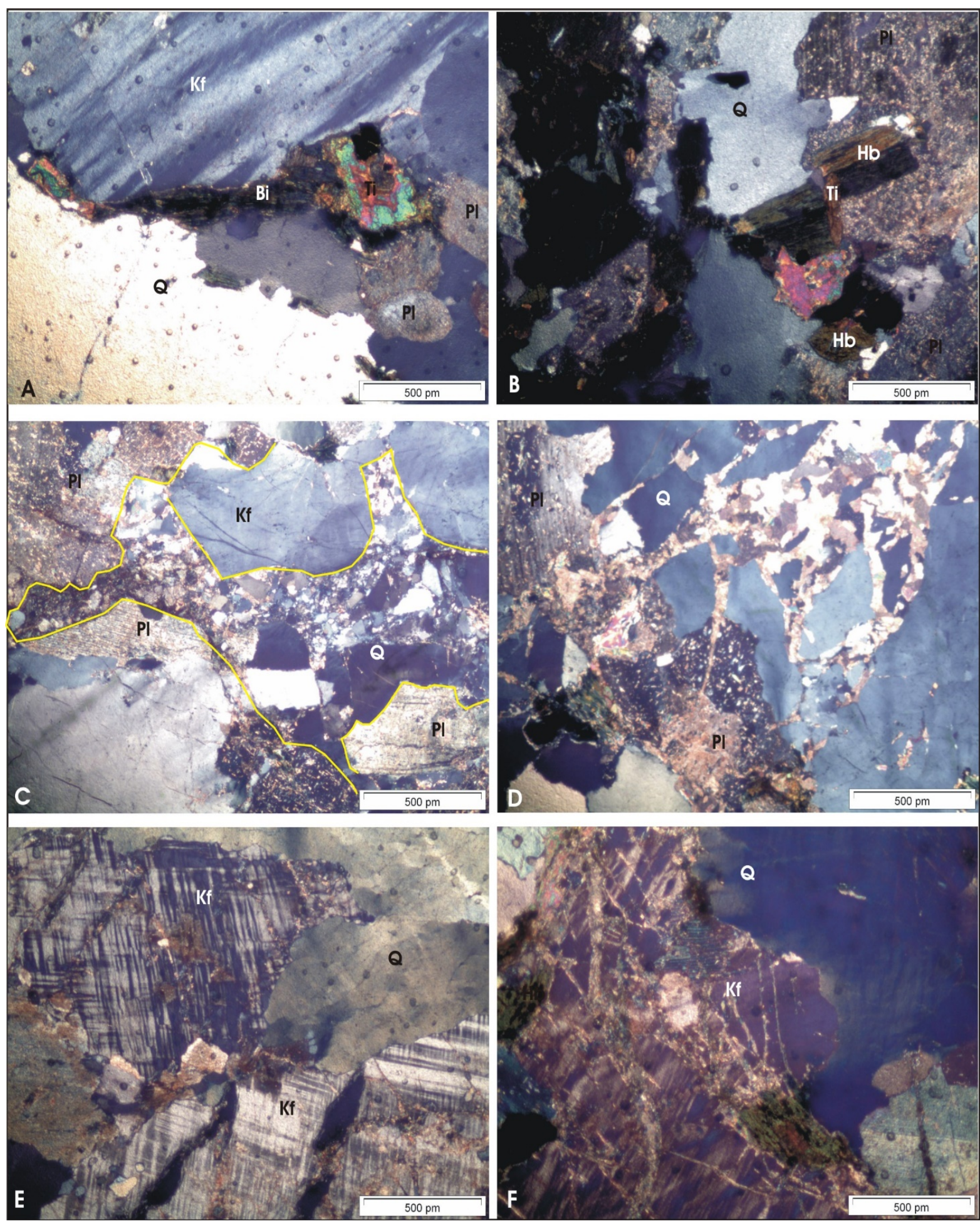

Figure 5. Summary photomicrograph of the Falombo intrusion. See text for discussion (A): pink K-feldspar megacrysts, set in a gray, equigranular, hypidiomorphic groundmass of subeuhedral plagioclase, anhedral microperthite, quartz, and biotite (B): mostly medium to coarse-grained and equigranular to weakly porphyric granite; (C), (D) and (E): microfractures and dissolution cavities commonly cut primary igneous K-feldspar exsolution lamellae in perthite grains newly formed albite occurred among K-feldspar and quartz; (F): K-feldspars show characteristics of slight brittle deformation, with sericite and carbonate aggregates filling in the micro-fractures of K-feldspar igneous K-feldspar, plagioclase, and quartz grains, but also follow planes of weakness that include the boundaries between individual grain. 
most continuous structures within this overall corridor on the property include the north-northeast trending Niakafiri, and Masato shear zones, which are high strain zones developed in altered ultramafic units. To the west of these, several shear zones are linked to them by subsidiary north to northwest trending splays. These include the "Ayoub's Thrust zone", which is focused along the ultramafic sill that lies on the west side (hangingwall) of the Sabodala deposit (Figure 6), shear zones which extend southward from this in the Sutuba and Soukhoto and Niakafiri West prospect areas, and the areas of high strain localized along the interflow chert-mudstone sedimentary horizon that has been locally termed the "mylonite". The north-northeast trending shear zones on the Sabodala property likely represent first and second order structures of regional scale, while the northwest trending shear zones may be third order features that accommodate strain between these higher order features. The latter locally intersect to form linking networks of locally developed shear zones that form important deposit scale controls on mineralization at other deposits in the region. Oblique fabric relationships, foliation trajectories of $S_{1}$, and local kinematic indicators are locally present in high strain zones/shear zones on the Sabodala property and suggest that a significant component of sinistral (left lateral) shear strain was accommodated along them.

Host shear zones parallel country rock-intrusion contacts and can occur along porphyry ultramafic contacts or basalt pelite. These shear zones have strongly developed planar and linear fabrics, which parallel the shear zone boundaries, and are best developed in ultramafic rock (Ayoub thrust). Talc-chlorite-serpentine to carbonate altered ultramafic sill that is 30 to $70 \mathrm{~m}$ wide, along which the "Ayoub's Thrust" is localized (Figure 6).

The dominant north-north-east-trending structural grain of the Sabodala Fault Zone is disrupted by a later system of northeast- and northwest striking faults (Figure 7). These northeast-striking faults have regional extent and have deformed units within the Mako Fold Belts (Figure 7). Later faults termed the "NW faults" strike northwest - southeast and overprint the earlier faults with extensive hydrothermal alteration (Figure 7). Theses faults are very planar features and dip steeply to the northeast. They are reverse faults with a component of dextral offset (Figure 7) and are interpreted as transfert fault. The final stage of brittle structures documented are a set of northwest-southeast.

\subsection{Mine Scale Shear Zones}

Confined in the Sabodala pit is a widespread fault system with complex crosscutting relationship and movement vector. Faults are represented by narrow zones of intense shearing separating either similar or different lithological units. The fault zones are dominated by intense mylonitization, drag folds, stretching lineation, steps, and slickensides. In the central part, they form two individual steeply dipping faults (the NW and Main Flat faults) (Figure 8) that lie on opposite limbs of the Sabodala antiform.

A porphyry dyke which intruded within the fault, is cross cut by NW- and N-trending faults. The Transfer Fault also corresponds to a linear boundary between the basalt and the dolerite in the Sabodala open pit area (note line of arrows on the geological map in Figure 2). The NW-trending Transfer Fault shows complex relationships with the other major N- and NW structural trends containing gold deposits within the study area. Some segments of the Transfer Fault are strongly mineralized with high gold grades recorded on the fault plane and in
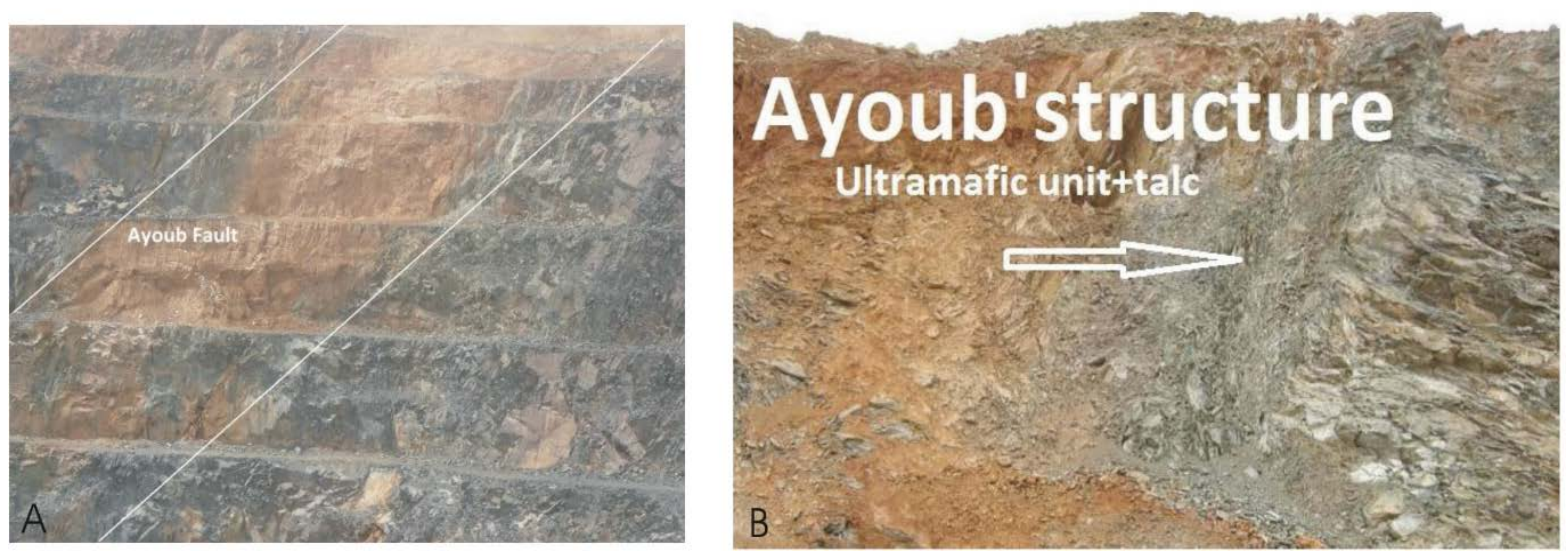

Figure 6. Structural photographs of the Ayoub fault: (A) Ayoub thrust; (B) Ayoub fault with strong ultramafic+ talc alteration. 

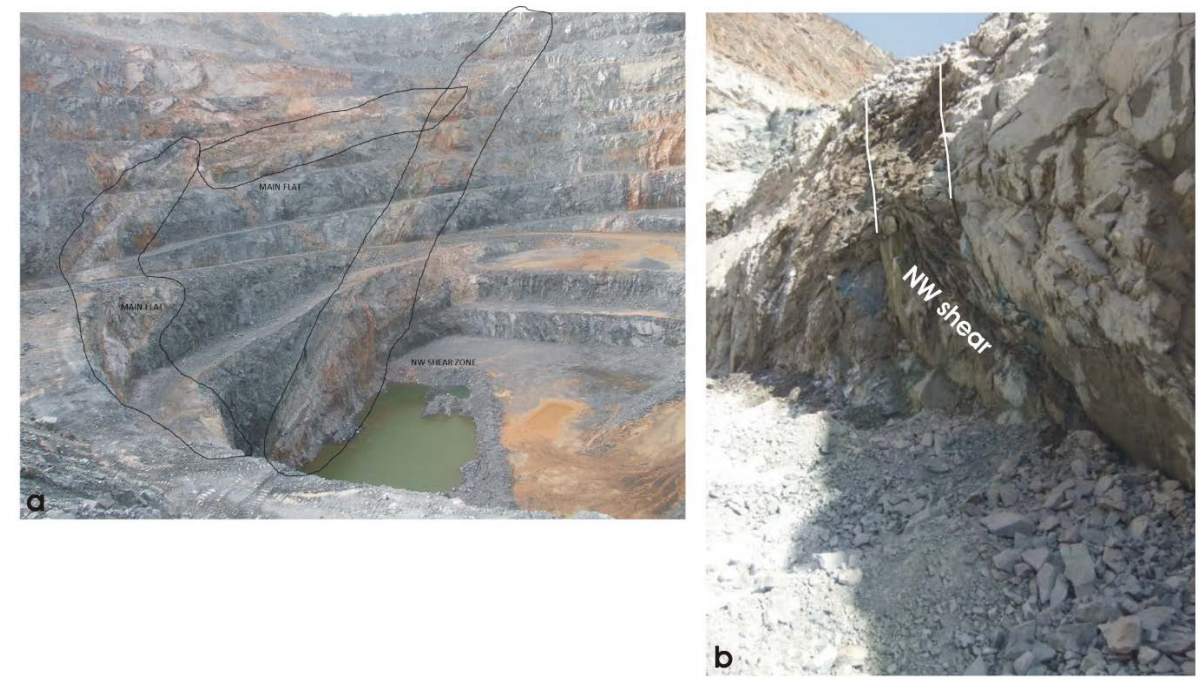

Figure 7. Structural photograph of the Northwest (NW) and main flat structures in the Sabodala Pit.
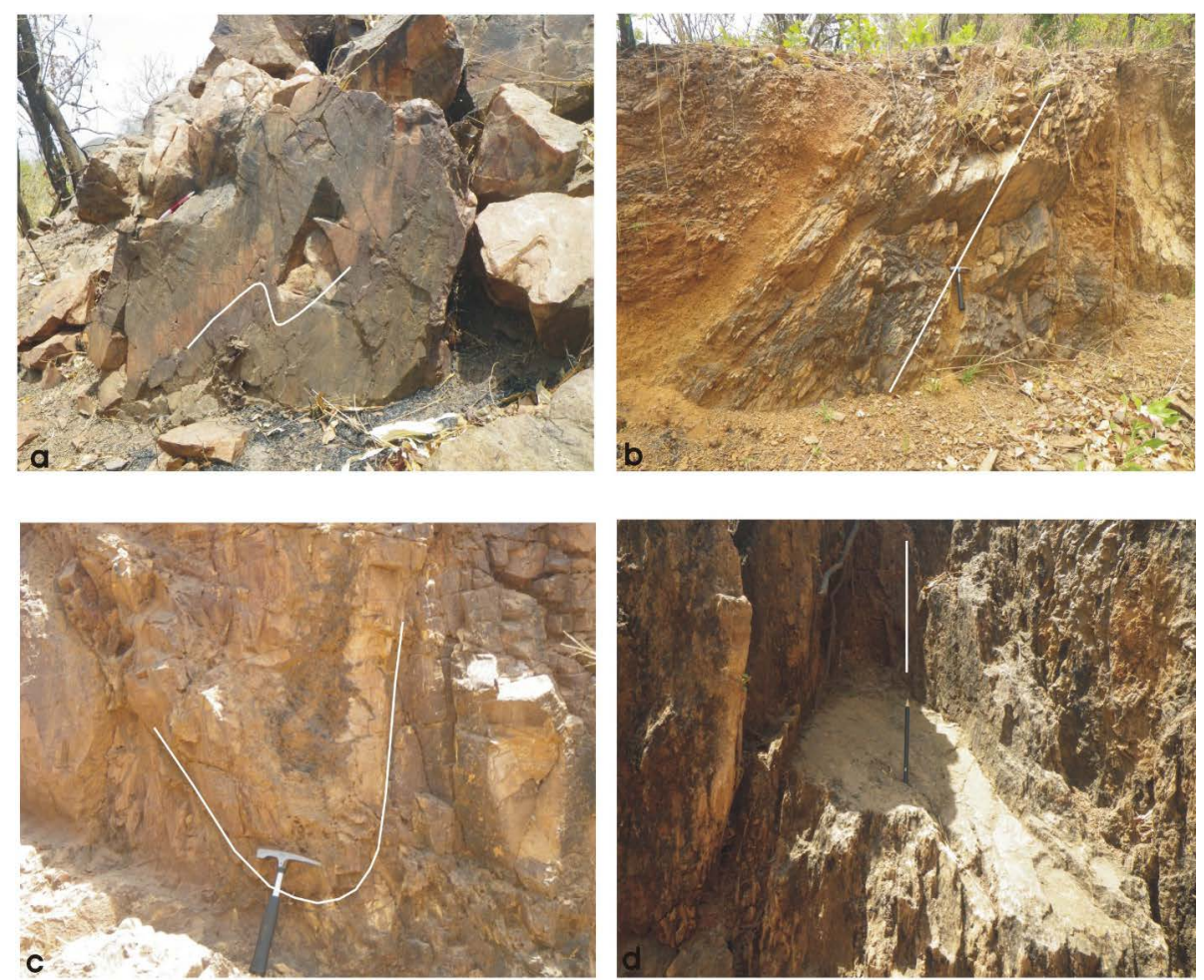

Figure 8. Photograph of folds showing in the Sabodala area: (a) folding of mylonitic chert north of Sabodala deposit; (b) asymmetric folding north of Sabodala; (c) and (d) folded rocks in western margin of the Niakafiri shear zone in southern parts of the Sabodala property.

adjacent wallrock (Figure 7). High-grade gold lodes occur in regions where the Transfer Fault intersects major flat lying shears, such as the Main flat Fault (Figure 7(a)).

Low-angle striations, linked to sinistral-reverse movement, have been observed on the NW-Fault. The Ayoub Fault, and Mylonite Fault, both exhibit strong ductile fabric development. Moderately dipping, narrow thrust planes, with a strike parallel to the main foliation, such as that formed around the margins of a folded porphyry are interpreted to be related to the main deformation in this zone. This is because the main deformation zone, the 
thrust planes and the folded porphyry, all accommodate the same strain characterized by horizontal shortening perpendicular to the dominant foliation and vertical extension.

The mineralized Main Flat structure terminates against the Ayoub Fault zone (Figure 2). The Main flat structure is one of the major mineralized shears in the Sabodala deposit (Figure 7(a)).

In contrast the NW trending mineralized structure clearly cross cuts the Main flat in the Sabodala Pit (Figure 7(b)). The NW-trending lodes are notable for their intense quartz-carbonate-pyrite-albite alteration associated with mineralization.

The NW-trending Transfer Fault shows complex relationships with the other major N- and NE structural trends containing gold deposits within the study area. Some segments of the NW Fault are strongly mineralized with high gold grades recorded on the fault plane and in adjacent wallrock. High-grade gold lodes occur in regions where the NW Fault intersects Main flat shears. The NW Shear is a grade controlling fault within the pit. The N-trending fault that hosts the Sabodala deposit also terminates against a shallow-dipping NW-trending fault that splays from the Ayoub Shear.

\subsection{Foliations}

At Sabodala all supracrustal rocks are moderately to intensely foliated. The strike of the regional foliation changes from NNW in the north to NNE in the south. The dip in the northern part of the mineralization is generally subvertical. In the central and southern parts of the deposit, the dip is slightly less steep. Primary structures, such as bedding planes $\left(\mathrm{S}_{0}\right)$, are rare in the metasupracrustal rocks. However, in a few outcrops, inferred primary bedding planes, parallel to the foliation, can be seen. The regional foliation is interpreted as $S_{1}$ since it is axial planar to minor isoclinal folds that fold these inferred primary bedding planes $\left(\mathrm{S}_{0}\right)$. These upright folds (with subhorizontal fold axes) are interpreted as $\mathrm{F}_{1}$ folds.

\subsection{Folds}

\subsubsection{Large-Scale Folds}

The structure of the Sabodala is dominated by two major N-trending folds (Sambaya and Sabodala antiforms, the west and east syncline and minor parasitic folds (Niakafiri Antiform) located in the southern end of the Sabodala dome. Some of the folds in Figure 8 are taken from recent compilation maps, whereas other, previously unrecognized folds are interpreted from the aeromagnetic map that will be discussed below. To the south of the Falombo-Sabodala fault zone, the folds have more northeasterly trends and some of the folds to the north of the Masato fault zone have ESE trends. The Sambaya antiform is one of the first-order regional folds. There are two significant megascopic folds with NNE-SSW to ESE-WNW orientation in the study area (Figure 8). From west to east, these folds are Sabodala antiform, Sambaya antiform, Masato antiform. The Sabodala anti-form plunges gently towards the north. It is asymmetric with steeply NW-dipping limbs. The Sambaya antiform is by far the most continuous fold. It is upright, tight, and slightly asymmetric and plunges gently towards the NNE. The Sabodala antiform has a similar orientation and plunge to that of the Sambaya antiform. They are bounded by steep reverse faults and the turbidites are folded into tight upright folds in Niakafiri.

\subsubsection{Mesoscopic Folds}

Mesoscopic folds are mostly found on the flanks of the megascopic folds (Figure 8). They have variable styles distinguishing two folding events, namely $F_{1}$ and $F_{2}$. $F_{1}$ folds are represented in the western part of the study area by intrafolial, asymmetric, overturned, tight folds (Figure 8(a) \& Figure 8(d)) with sub-vertical axes. $F_{2}$ folds overprint $F_{1}$ folds and are represented in the central and eastern parts of the study area by mesoscopic folds (Figure 8(b) \& Figure 8(c)). The $\mathrm{F}_{2}$ mesoscopic folds are of the same generation and have the same WNW-ESE orientation and a gentle plunge as the megascopic folds.

\subsection{Veining and Alteration Associated with Mineralization}

The mineralisation within the pit is associated with moderate-dipping quartz vein arrays that trend NW and are parallel to the N- and NE-dipping NW Shear. The mineralized veins within the Main Flat have distinctive intense wallrock alteration that is mineralized (Figure 7). This alteration is dominantly quartz, carbonate, pyrite and sericite. Steeply NEdipping NW-trending faults occur in the Sabodala Area (Figure 7). In some strike seg- 
ments this has been formally named the NW Fault, and will be referred to as the NW Fault in this paper. While all of the units in the deposit area mentioned above may host gold mineralization, most extensive mineralized areas in central portions of the deposit adjacent to the ore controlling Main Flat and Northwest shear zones are localized in the "volcaniclastic" and adjacent mylonitic chert units where they are affected by extensive albite-carbonate-pyrite alteration and quartz-carbonate-albite vein development associated with shear zone networks. Sabodala-style-mineralization is characterized by major breccia orebodies and a high abundance of pyrite, gold, telluride...etc and is well developed along the Sambaya antiform. Gold mineralization of all styles is associated with pyrite in association with extension and shear veins as clots, grains and along slip surfaces within veins, as pervasively disseminated envelopes around veins, and is also disseminated in broad zones of carbonate-albite alteration surrounding shear veins. Locally pyrite forms veinlets, which both cut across, and in other areas are cut by, quartz-carbonate albite veins, suggesting multiple pyrite generations, occurring within both pyrite veinlets and quartz-carbonate veinlets. Pyrite is variable in grain size and ranges from cubic to anhedral. Pyrite of all grain sizes from mineralized zones is spatially associated with grains of native gold along crystal margins, in fractures within pyrite, or encapsulated in pyrite grains. Trace, often very fine-grained chalcopyrite and locally galena occur as minute grains in or adjacent to pyrite often spatially associated with gold. The controlling structures to mineralization may have initially formed during $\mathrm{D}_{1}$ on the $\mathrm{S}_{1}$ foliation in response to north-south to north-northwest, south-southeast directed shortening. This phase of deformation is associated with regional apparent left-lateral (sinistral) displacement on shear zones, including Ayoub's thrust, which was associated with early, premineralization carbonate alteration. East-west trending and steeply dipping oblique foliation in the Northwest Shear, which is overprinted by later $\mathrm{S}_{2}$ fabric, suggests that that structure was active during $\mathrm{D}_{1}$ and accommodated right lateral/reverse displacement, probably coeval with and conjugate to significant top to the southeast displacement on the Main Flat and "New Fault". Early veins which include boudinaged, more highly strained foliation parallel sets, steeply dipping northeast trending extension veins, and potentially early shear veins along the main structures, likely formed progressively during $\mathrm{D}_{1}$. Hydrothermal alteration is a really extensive and structurally controlled. For Sabodala style mineralization, Gueye et al., [10] reported primary $\mathrm{H}_{2} \mathrm{O}-\mathrm{NaCl}-\mathrm{CO}_{2}$ inclusions with low salinities (8.0 - $19 \mathrm{wt} \% \mathrm{NaCl}$ equiv), homogenization temperature between $220^{\circ} \mathrm{C}-330^{\circ} \mathrm{C}$ and pressure between 1.4 and $2.75 \mathrm{Kbar}$. Gueye et al., [10] interpreted gold deposition and wallrock alteration to be contemporaneous with development of the different lode structure and suggest that mineralization was late in the deformation sequence. Gold mineralization at the Sabodala deposit occurs in a combination of continuous grey quartz shear veins along shear zone surfaces in the main flat and northwest shear zones, in sets of quartz carbonate-albite-pyrite extension veins, in coalescing extension and shear vein domains which form zones of quartz-carbonate matrix breccia, and in areas of pervasive tan to pink coloured carbonate albite-sericite-pyrite alteration which surrounds and links between veins, shear zones and breccia Sabodala style mineralization is characterized by major breccia orebodies and a high abundance of pyrite, free gold, tellurides, and is well developed along the Sambaya Antiform. Multiple generations of veins are evident, but the most voluminous veining and alteration forms the youngest generations. The veining is structurally late, and both veins and alteration exhibit low post mineralization strain, crossing and largely overprinting $S_{1}$ and $S_{2}$ fabrics. Veins are deformed however in shear zones associated with the Main Flat and Northwest Shear, but this strain probably reflects late, continuing syn-mineralization displacement along mineralized structures.

The most continuous mineralization occurs along and surrounding the Main Flat and Northwest Shear. In the central parts of the deposit, these two structures are cored by quartz shear vein systems comprising mottled grey, variably brecciated, and banded quartz veining which is locally host to high gold grades. These central shear veins are typically surrounded by intense, often brecciated alteration with auriferous white quartz-carbonatealbite veinlets. These structures vary from narrow ductile sericite-carbonate-chlorite altered shear zones locally containing a central shear vein in distal parts of the Sabodala deposit, to shear zones with a central shear vein locally $>5 \mathrm{~m}$ thick or a series of closely spaced veins over intervals of 3 to $10 \mathrm{~m}$ in some parts of the core of the deposit where mineralization is best developed. Immediately beneath or along strike from the quartz shear veins in the main structures, the proximal alteration often comprises a muscovite-carbonate altered shear zone that may be several meters thick, also forming part of the shear zone slip surfaces. The shear zone is often strongly foliated, and may contain oblique internal shear fabrics. This foliated zone and the slip surfaces in the vein probably accommodate much of the synmineralization displacement along the Main Flat, probably late in its structural history. Quartz-carbonate veins are often transposed into foliation surfaces. Hydrothermal alteration is already extensive and structurally controlled. A broad zone of carbonate chlorite alteration replaces regional 
greenschist facies metamorphic assemblages and is present as a wide zone centered on the Sabodala fault and more locally around subsidiary third-order fault zones. Locally structurally controlled regional ankerite-sericite alteration overprints the chlorite-calcite alteration and also pervasively developed in areas in the Niakafiri basalts.

\section{Structural Observations and Mapping within the Sabodala Region}

\subsection{Revised Structural Interpretation for the Sabodala Region}

The Sabodala Goldfield has undergone multiple episodes of Eburnean deformation (Diene et al., [39], Gueye et al., [10]) and is bounded by the NNE-trending SSC to the west, and by the Masato-Makana Fault to the east. The major deformation event within the field as described by previous works (Diene et al., [39], Gueye et al., [10]), was an ENE-WNW shortening event that produced thrusts and upright, NNW-trending, gently plunging folds.

At a deposit-scale the structure of the goldfield is dominated by thrust repetitions of stratigraphy $\left(D_{1}\right)$ and broad anticlinal features, such as the Sabodala and Sambaya domes. The Sabodala deposit is bound to the west by a NNE to NE trending Ayoub thrust fault, which is considered part of the eburnean deformation. Late deformation also caused sinistral reactivation. The 2D map patterns show that the Sabodala area is dominated by a regional northeast to north northeast structural grain defined by major faults, gently-plunging upright regional folds, and foliation development.

The structural style in the Sabodala sector characterized by a regional pattern of asymmetric S-fold and sinistral decollement surfaces (Figure 2) is explained by late sinistral transcurrent movement on originally N-trending rock units $\left(D_{2}\right)$. The main structure that links Sabodala and Makana is the Sabodala Shear Corridor (SSC), which hosts the Sabodala Mine and Niakafiri orebodies.

The dominant geologic structures at Sabodala are the Sabodala and Sambaya antiforms, which expose a sequence of mafic and ultramafic rocks in their core, intruded by a number of granitic dikes (porphyries) and differentiated dolerite sills, and overlain by the felsic volcaniclastic rocks of the Mako Group. The exposed stratigraphy is similar to that of the Makana neighboring areas. The Sabodala shear zone truncates the folds, and the main gold deposits at Sabodala gold field tend to occur within or immediately adjacent to the Sabodala shear zone.

The dominant anticlinal fold axis through Sambaya and Sabodala has been related to this event. This deformation was associated with marked flattening, the formation of a regional fabric and is linked to peak regional metamorphism. In this area major crustal thickening was accommodated via ductile deformation along the regional first order Ayoub Fault, and also the NW Fault which is inferred to be a second order splay fault (Figure 2). Felsic to intermediate intrusive rocks was emplaced at a late stage in $D_{2}$ and also post- $D_{2}$. At the Sabodala mine, mineralization is bound by the Mylonite fault in the east and the hangingwall Ayoub shear in the west (Figure 2).

A revised structural interpretation of the Sabodala Goldfield is presented in Figure 9. This was developed on the basis of mapping and integrates existing 2D and 3D structural models with geophysical data sets (magnetic), and regional grade contours of gold grade. This was combined with open pit geological mapping, and also sectional interpretations. The new structural interpretation (Figure 9) has been integrated with the currently defined rock type distributions. This paper uses the recent deformation scheme and ages compiled by Diene et al., [39]; Gueye et al. [10]. Sequence repetition is particularly evident where the lower mafic-ultramafic stratigraphy has been uplifted and exposed at the margins of granitic domes. The last major deformation event in the Sabodala Goldfield was related to the formation of NNE- to NE-trending dextral strike-slip faults.

In summary, the structures documented in this district suggest a change from a $\mathrm{D}_{2}$ horizontal shortening and vertical extension event giving rise to the dominant northeast-southwest-trending fabric, to a $\mathrm{D}_{3}$ north-northwesttrending dextral shearing. Late exhumation resulted in extension along fault zones and was responsible for the juxtaposition of medium and low grade metamorphic rocks. The granitic suite of the Falombo pluton is linked to this exhumation.

\subsection{Discussion and Conclusion}

The Sabodala area is a key to understanding the early fault architecture because of the lack of pervasive high-strain overprint. It is a type locality for defining the nature and timing of the NW-trending structures. 


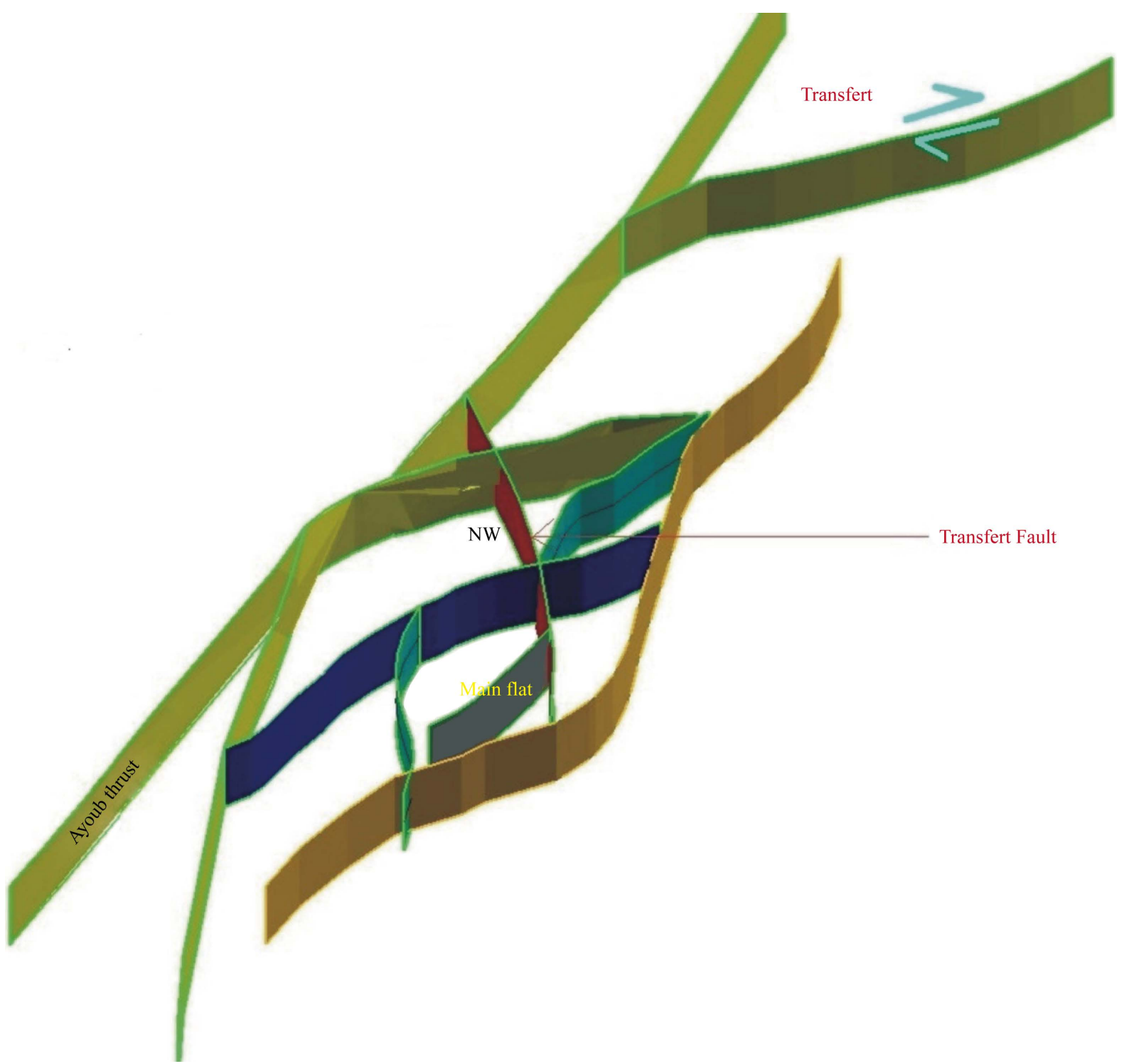

Figure 9. Summary diagram of kinematic relationships at the pit the Transfer Fault intersects the Main flat and the later terminates against the Transfer Fault. See text for discussion.

In this paper an attempt is made to describe the geometry, structure and mineralization of the auriferous quartz vein system of the Sabodala area. The structural evidence presented above strongly suggests that gold was deposited in brittle-ductile shear zones during two distinct episodes of eburnean tectonics on a retrograde P-T path. This is stressed by the following points:

- the presence of relicts of mylonitic rocks in the auriferous Sabodala shear zones suggests that ductile $\mathrm{D}_{2}$ shear zones were reactivated in a strike-slip to oblique-slip system during the $\mathrm{D}_{3}$ event. Fault-valve behavior produced laminated quartz veins during $\mathrm{D}_{3}$.

- alteration and ore minerals show replacement textures, so that two different parageneses can be distinguished, which are both associated with gold.

- two-stage gold mineralization postdates peak metamorphism on the retrograde path. Microstructures of $\mathrm{D}_{3}$ and the associated mineralogy suggest temperatures of $200^{\circ} \mathrm{C}-250^{\circ} \mathrm{C}$ for the second gold mineralizing event (Gueye et al., [10]). The tectono-metamorphic evolution shown for Mako can be linked to two regional events:

1) the greenschist facies assemblage of the KKI and, 
2) a late-tectonic inlier-wide magmatic event between $2050 \mathrm{Ma}$ and $2080 \mathrm{Ma}$.

These regional tectonic events probably triggered the two-phase fluid infiltration to the auriferous shear zone system at Mako. The controlling structures to mineralization may have initially formed during $D_{1}$ on the $S_{1}$ foliation in response to north-south to northnorthwest, southsoutheast directed shortening. This phase of deformation is associated with regional apparent left-lateral (sinistral) displacement on shear zones, including Ayoub's thrust, which was associated with early, premineralization carbonate alteration. East-west trending and steeply dipping oblique foliation in the Northwest Shear, which is overprinted by later $\mathrm{S}_{2}$ fabric, suggests that structure was active during $\mathrm{D}_{1}$ and accommodated right lateral/reverse displacement, probably coeval with and conjugate to significant top to the southeast displacement on the Main Flat and "New Fault". Early veins which include boudinaged, more highly strained foliation parallel sets, steeply dipping northeast trending extension veins, and potentially early shear veins along the main structures, likely formed progressively during $\mathrm{D}_{1}$. A complex 3D array of linked strike-slip, reverse and normal faults interact with the antiform and associated domes. Many of these faults reactivated an earlier extensional basin-forming fault system, producing the complex variations in the location and characteristics of the region's ore bodies.

A new structural model is presented for the formation of the Sabodala deposit orebodie. We consider the narrow zone of deformed ultrabasite (Ayoub thrust) in the western limb of the antiform as an early thrust fault. One of the striking features of the NW-trending Transfer Fault is that it has only developed high-grade gold mineralization in localized regions (the direction of the maximum shortening strain). In the Sabodala area an early period of N-S directed thrust stacking and isoclinal folding has produced repetitions in the mafic-ultramafic statigraphy, and on associated layerparallel fabric. Later structural events produced N- to NE-trending folds, NE- to E-trending folds, NE- and NW-trending brittle - ductile shear zone and E-trending shear zone. The different structures have distincts geometries and crosscutting relationships and can be classified as $D_{2}$. They formed during a single, progressive deformation event, broadly synchronous with peak metamorphism and granitoid intrusion. The deformation associated with the Sabodala deposit has a close affinity to the Falombo pluton and the porphyry dykes and can be termed a magmatic associated or intrusion related deposit (e.g. Bierlein et al., [40]; Miller and Wilson, [41]). Miarolitic cavities and the contact metamorphic assemblage adjacent to the pluton indicate a depth of intrusion of less than $5 \mathrm{~km}$ and suggest diapiric emplacement at shallow levels. At least some of the deformation is post contact metamorphic associated with the granodiorite phase of the Falombo pluton (Figure 4).

Gold lodes developed during brittle deformation associated with high fluid pressures in a northwest-southeast and then east-west shortening regime (Gueye et al., [10]). Heterogeneous stress patterns were developed in the Sabodala area during the emplacement of the Falombo pluton and locally distributed the NW-SE compressional stress regime active across the Mako Belt in the Eburnean.

The strain pattern (deformation) within and around the pluton can be explained in terms of diapirism, where the intrusion ascends and squeezes and shears its outer part and the surrounding country rock to create space. Quartz-feldspar porphyries, quartz diorite, microdiorite which occur as sills, dykes and minor stocks, were intruded prior to $D_{2}$ along preexisting structural discontinuities particularly lithological contacts and $S_{1}$ foliation planes.

$\mathrm{D}_{2}$ structures all host gold mineralization in the Sabodala Gold filed. In each of these structures, textural evidence indicates that mineralization was synchronous with deformation. Gold deposit in the Sabodala area occurs as faultbounded quartz veins sets and as shear zone replacements along porphyry sill-ultramafic rock contacts, indicating that contacts and competency contrast between lithological units are important structural control on the siting of gold mineralization. This study has demonstrated that granitic plutons emplaced at the time of mineralization and metamorphism may play a major role in determining the style and distribution of gold related wallrock alteration assemblage at the mine scale.

Furthermore, most of the gold mineralization in other Birimian terranes is related to steeply dipping structures in and around schist belts. The observations at Sabodala thus suggest that gold mineralization in the Birimian terranes of West Africa may occur in different structural settings. Consequently, Sabodala raises the possibility that large areas of underexplored ground exist in the Birimian of West Africa.

\section{Acknowledgements}

Data presented in this paper formed the basis of a Ph.D. project carried out by Serigne Sylla. Financial and scientific support from Teranga Gold Coporation is gratefully acknowledged. Special thanks must go to compa- 
ny Exploration Manager Peter Mann for his valuable contribution.

\section{References}

[1] Eisenlohr, B.N. and Hirdes, W. (1992) The Structural Development of the Early Proterozoic Birimian and Tarkwaien Rokcs of Southwest Ghana, West Africa. Journal of African Earth Sciences, 14, 313-325. http://dx.doi.org/10.1016/0899-5362(92)90035-B

[2] Blenkinsop, T.G., Schmidt Mumm, A., Kumi, R. and Sangmor, S. (1994) Structural Geology of the Ashanti Gold Mine, Obuasi, Ghana. Geologische Jahrbuch, D100, 131-154.

[3] Mumin, A.H. and Fleet, M.E. (1995) Evolution of Gold Mineralization in the Ashanti Gold Belt, Ghana: Evidence from Carbonate Compositions and Parageneses. Mineralogy and Petrology, 55, 265-280. http://dx.doi.org/10.1007/BF01165121

[4] Oberthür, T., Schmidt-Mumm, A., Vetter, U., Simon, K. and Amanor, J.A. (1996) Gold Mineralisation in the Ashanti Belt of Ghana: Genetic Constraints of the Stable Isotope Geochemistry. Economic Geology, 91, 289-301. http://dx.doi.org/10.2113/gsecongeo.91.2.289

[5] Oberthür, T., Vetter, U., Davis, D.W. and Amanor, J.A. (1998) Age Constraints on Gold Mineralization and PaleoProterozoic Crustal Evolution in the Ashanti belt of Southern Ghana. Precambrian Research, 89, 129-143. http://dx.doi.org/10.1016/S0301-9268(97)00075-2

[6] Yao, Y., Murphy, P.J. and Robb, L.J. (2001) Fluid Characteristics of Granitoid-Hosted Gold Deposits in the Birimian Terrane of Ghana: A Fluid Inclusion Microthermometric and Raman Spectroscopic Study. Economic Geology, 96, 1611-1643. http://dx.doi.org/10.2113/gsecongeo.96.7.1611

[7] Allibone, A., Teasdale, J., Cameron, G., Etheridge, M., Uttley, P., Soboh, A., Appiah-Kubi, J., Adanu, A., Arthur, R., Mamphey, J., Odoom, B., Zuta, J., Tsikata, A., Pataye, F., Famiyeh, S. and Lamb, E. (2002) Timing and Structural Controls on Gold Mineralization at the Bogoso Gold Mine, Ghana, West Africa. Economic Geology, 97, 949-969. http://dx.doi.org/10.2113/gsecongeo.97.5.949

[8] Feybesse, J.L., Billa, M., Guerrot, C., Duguey, E., Lescuyer, J.L., Milési, J.P. and Bouchot, V. (2006) The PaleoProterozoic Ghanaian Province: Geodynamic Model and Ore Controls, Including Regional Stress Modeling. Precambrian Research, 149, 149-196. http://dx.doi.org/10.1016/j.precamres.2006.06.003

[9] Harcouët, V., Guillou-Frottier, L., Bonneville, A. and Feybesse, J.L. (2005) Pre-mineralization Thermal Evolution of the Palaeoproterozoic Gold-Rich Ashanti Belt, Ghana. Geological Society Special Publication, 248, 103-118. http://dx.doi.org/10.1144/GSL.SP.2005.248.01.05

[10] Gueye, M., Van den Kerkhof, A., Hein, U.F., Siegesmund, S., Diene, M. and Mücke, A. (2013) Structural Control, Fluid Inclusions and Cathodoluminescence Studies of Birimian Gold-Bearing Quartz Vein Systems in the Paleoproterozoic Mako Belt (SE-Senegal). South African Journal of Geology, 116, 199-218. http://dx.doi.org/10.2113/gssajg.116.2.199

[11] Sylla, M., Ngom, P.M. (1997) Le gisement d’or de Sabodala (Sénégal Oriental): Une minéralisation filonienne d'origine hydrothermale remobilisée par une tectonique cisaillante. Journal African Earth Sciences, 25, 183-192. http://dx.doi.org/10.1016/S0899-5362(97)00097-3

[12] Bessoles, B. (1977) Géologie de l’Afrique: Le craton ouest-africain. Mémoires BRGM, 88 Paris.

[13] Abouchami, W., Boher, M., Michard, A. and Albarede, F. (1990) A Major 2.1 Ga Old Event of Mafic Magmatisme in West Africa: An Early Stage of Crustal Accretion. Journal Geophysical Research, 95, 17605-17629. http://dx.doi.org/10.1029/JB095iB11p17605

[14] Boher, M., Abouchami, W., Michard, A., Albarède, F. and Arndt, N.T. (1992) Crustal Growth in West Africa at 2.1 Ga. Journal of Geophysical Research, 97, 345-369. http://dx.doi.org/10.1029/91JB01640

[15] Taylor, P.N., Moorbath, S., Leube, A. and Hirdes, W. (1992) Early Proterozoic Crustal Evolution in the Birimian of Ghana: Constraints from Geochronology and Isotope Geochemistry. Precambrian Research, 56, 97-113. http://dx.doi.org/10.1016/0301-9268(92)90086-4

[16] Dia, A., Van Schmus, W.R. and Kröner, A. (1997) Isotopic Constraints on the Age and Formation of a Paleo-Proterozoic Volcanic Arc Complex in the Kedougou Inlier, Eastern Senegal, West Africa. Journal of African Earth Sciences, 24, 197-213. http://dx.doi.org/10.1016/S0899-5362(97)00038-9

[17] Pawlig, S., Gueye, M., Klischies, R., Schwars, S., Wemmer, K. and Siegesmund, S. (2006) Geochemical and Sr-Nd Isotopic Data on the Birimian of the Kedougou-Kenieba Inlier (Eastern Senegal): Implications on the Palaeoproterozoic Evolution of the West African Craton. South African Journal of Geology, 109, 411-427. http://dx.doi.org/10.2113/gssajg.109.3.411

[18] Bohomme, M. (1962) Contribution à l'étude géochronologique de la plate-forme de l'Ouest africain. Thèse d'état, Ann. 
Fac. Sci, Univ Clermont-Ferrand, Fr., Geologie Mineralogie, 5, 62 p.

[19] Liégeois, J.P., Claessens, W., Camara, D. and Klerx, J. (1991) Short-Lived Eburnian Orogeny in Southern Mali. Geology, Tectonics, U-Pb and Rb-Sr Geochronology. Precambrian Research, 50, 111-136. http://dx.doi.org/10.1016/0301-9268(91)90050-K

[20] Gueye, M., Ngom, P.M., Diène, M., Thiam, Y., Siegesmund, S., Wemmer, K. and Pawlig, S. (2008) Intrusiv Rocks and Tectonic Evolution of the Paleoproterozoic Rocks of the Mako Paleoproterozoic Belt (Eastern Senegal, West Africa). Journal African Earth Sciences, 50, 88-111. http://dx.doi.org/10.1016/j.jafrearsci.2007.09.013

[21] Gueye, M., Siegesmund, S., Wemmer, K., Pawlig, S., Drobe, M. and Nolte, N. (2007) New Evidences for an Early Birimian Evolution in the West African Craton: An Example from the Kédougou-Kénieba Inlier, SE-Senegal. South African Journal of Geology, 110, 511-534. http://dx.doi.org/10.2113/gssajg.110.4.511

[22] Hirdes, W. and Davis, D.W. (2002) U-Pb Geochronology of Paleoproterozoic Rocks in the Southern Part of the Kédougou-Kéniéba-Inlier Sénégal, West Africa: Evidence for Diachronous Accretionary Development of the Eburnean Province. Precambrian Research, 118, 83-99. http://dx.doi.org/10.1016/S0301-9268(02)00080-3

[23] Diene, M., Gueye, M., Diallo, D.P. and Dia, A. (2012) Structural Evolution of a Precambrian Segment: Example of the Paleoproterozoic Formations of the Mako Belt (Eastern Senegal, West Africa). International Journal of Geosciences, 3 , 153-165. http://dx.doi.org/10.4236/ijg.2012.31017

[24] Leube, A., Hirdes, W., Mauer, R. and Kesse, G.O. (1990) The Early Proterozoic Birimian Supergroup of Ghana and Some Aspects of Its Associated Gold Mineralisation. Precambrian Research, 46, 139-165. http://dx.doi.org/10.1016/0301-9268(90)90070-7

[25] Feybesse, J.L., Milési, J.P., Ouédraogo, M.F. and Prost, A.E. (1990) La ceinture Protérozoïque inférieur de Boromo Goren (Burkina-Faso): Un exemple d'interférence entre deux phases transcurrentes éburnéennes. Comptes Rendus de l'Académie des Sciences, 310, 1353-1360.

[26] Ledru, P., Pons, J., Milési, J.P., Dommanget, A., Johan, V., Diallo, M. and Vinchon, C. (1989) Tectonique transcurrente et évolution polycyclique dans le birimien, protérozoïque inférieur, du Sénégal-Mali (Afrique de l'ouest). Comptes Rendus de l'Académie des Sciences, 308, 117-122.

[27] Milési, J.P., Ledru, P., Feybesse, J.L., Dommanget, A. and Marcoux, E. (1992) Early Proterozoic Ore Deposits and Tectonics of the Birimian Orogenic Belt, West Africa. Precambrian Research, 58, 305-344. http://dx.doi.org/10.1016/0301-9268(92)90123-6

[28] Hirdes, W., Davis, D.W. and Eisenlohr, B.N. (1992) Reassessment of Proterozoic Granitoid Ages in Ghana on the Basis of U/Pb Zircon and Monazite Dating. Precambrian Research, 56, 89-96. http://dx.doi.org/10.1016/0301-9268(92)90085-3

[29] Davis, D.W., Hirdes, W., Schaltegger, U. and Nunoo, E.A. (1994) U-Pb Constraints on Deposition and Provenance of Birimian and Gold-Bearing Tarkwaian Sediments in Ghana, West Africa. Precambrian Research, 67, 89-107. http://dx.doi.org/10.1016/0301-9268(94)90006-X

[30] Doumbia, S., Pouclet, A., Kouamelan, A., Peucat, J.J., Vidal, M. and Delor, C. (1998) Petrogenesis of Juvenile-Type Birimian (Paleoproterozoic) Granitoids in Central Cote-d'Ivoire West Africa: Geochemistry and Geochronology. Precambrian Research, 87, 33-63. http://dx.doi.org/10.1016/S0301-9268(97)00201-5

[31] Bassot, J.P. (1987) Le complexe volcanoplutonique calco alcalin de la rivière Daléma (Est du Sénégal): Discussion de la signification géodynamique dans le cadre de l’orogenèse éburnéenne (Protérozoïque inférieur). Journal African Earth Sciences, 6, 25-34.

[32] Ngom, P.M, Guéye, M. and Cissokho, S. (2005) An Early Tectonic Phase in the Paleoproteroroic. Incidences on the Geodynamic Evolution of the Mako Volcanic Belt. (Kedougou Kenieba Inlier. Senegal). Abstract, III éme Colloque PICG 485, Gao.

[33] Bassot, J.P. (1966) Etude géologique du Sénégal oriental et de ses confins guinéo-maliens. Mémoire du Bureau Recherche Géologique et Minière, No. 40, 332 p.

[34] Cheilletz, A., Barbey, P., Lama, C., Pons, J., Zimmerman, J.L. and Dautel, D. (1994) Age de refroidissement de la croûte juvénile birimienne d'Afrique de l'Ouest. Données U-Pb, Rb-Sr et K-Ar sur les formations à 2.1 Ga du SW Niger. Compte Rendu de l'Academie des Sciences, 319, 435-442.

[35] Pons, J., Barbey, P., Dupuis, D. and Léger, J.M. (1995) Mechanisms of Pluton Emplacement and Structural Evolution of a 2.1 Ga Juvenile Continental Crust: The Birimian of Southwestern Niger. Precambrian Research, 70, 281-301. http://dx.doi.org/10.1016/0301-9268(94)00048-V

[36] Dioh, E., Béziat, D., Debat, P., Grégoire, M. and Ngom, P.M. (2006) Diversity of the Palaeoproterozoic Granitoids of the Kédougou Inlier (Eastern Senegal): Petrographical and Geochemical Constraints. Journal of African Earth Sciences, 44, 351-371. http://dx.doi.org/10.1016/j.jafrearsci.2005.11.024

[37] Ngom, P.M. (1985) Contribution à l'étude de la série birimienne de Mako dans le secteur aurifère de Sabodala 
(Sénégal oriental). Thèse Doctorat de 3ème cycle, Université de Nancy I, Nancy, 134 p.

[38] Candela, P.A. and Blevin, P.L. (1995) Do Some Miarolitic Granites Preserve Evidence of Magmatic Volatile Permeability? Economic Geology, 90, 2310-2316. http://dx.doi.org/10.2113/gsecongeo.90.8.2310

[39] Diene, M., Fullgraf, T., Gloaguen, E., Gueye, M., Ndiaye, P.M. and Diatta, F.M. (2015) Review of the SenegaloMalien Shear Zone System-Timing, Kinematics and Implications for Possible Au Mineralisation Styles. Journal of African Earth Sciences, 112, 485-504. http://dx.doi.org/10.1016/j.jafrearsci.2015.05.004

[40] Bierlein, F.P., Arne, D.C., Keay, S.M. and McNaughton, N.J. (2001) Timing Relationships between Felsic Magmatism and Mineralisation in the Central Victorian Gold Province, Southeast Australia. Australian Journal of Earth Sciences, 48, 883-899. http://dx.doi.org/10.1046/j.1440-0952.2001.00907.x

[41] Miller, J.M. and Wilson C.J.L. (2002) The Magdala Lode System, Atawell, Southeastern Australia: Structural Style and Relationship to Gold Mineralization across the Western Lachan Fold Belt. Economic Geology, 97, 325-349. http://dx.doi.org/10.2113/gsecongeo.97.2.325 